\title{
THE CONCEPT OF PROPERTY LAW EXTRACTED FROM THEMATIC VERSES OF AL-QUR'AN
}

\author{
Burhanuddin \\ Fakultas Syariah Universitas Islam Negeri Maulana Malik Ibrahim \\ Email: burhanuddin@syariah.uin-malang.ac.id
}

\section{Abstract}

Artikel ini menjelaskan hasil penggalian bukum tentang harta dari ayat-ayat alQur'an. Untuk mencapai tujuan tersebut, penulisan diawali dengan melakukan klasifikasi ayat-ayat al-Quransecara tematik (maudluiyah); baik itu menggunakan lafadz al-mal secara langsung maupun lafadz lainny a yang berkaitan dengan harta. Ayat-ayat yang telah terkumpulkemudian akan digali menggunakan metode istinbath sehingga dapat diketahui hukum-hukum tentang harta. Keberadaan harta dari perspektif hukum al-Qur'an merupakan ujian Allah bagi manusia. Apabila ujian tersebut dapat dilalui dengan baik melalui ketaatan maka akan bernilai ibadah dari hasil pengamalan bukum-hukum harta baik yang bersifat perintah, larangan maupun kebolehan. Begitupula sebaliknya, kegagalan menghadapi ujian harta dapat menjerumuskan pemiliknya berbuat istidraj melalui kemaksiatan sehingga akan mendapatkan azhab Allah.

This study explains the results of extracting the law about property derived from the verses of al-Qur'an. To achieve this purpose, the writing is begun by classifying the verses inal-Qur'an thematically (maudluiyah); either using that term al-mal directly or other terms related to property. The collected versenthen will be analyzed using the method of istinbath, so the laws of propertyare discovered. Propertyfrom the perspective of al-Qur'an is God's examination for humans. If they pass the examination properly through obedience, it will be worth the worship as a result of law practice in the form of instruction (al-amr), prohibition (al-nahy) or permissibility (al-ibabab). On the contrary, the failure in examinationcan trigger the owners to do istidraj by doing immoral acts that cause them to be punished (azab) by God.

Keywords: al-Qur'an, istinbath, law, property (al-mal), 


\section{Introduction}

Property is an integral part of human life. Through ownership of those, a person can fulfill various basic needs of his life. Therefore, property is made beautiful in the view of human to be possessed (QS. Ali Imran [3]: 14) because it can help them to get various life necessities. Liking something that is revealed in the verse is the greatest lust of the world (a'dhamsyahwat al-dunya), while the others follow it. ${ }^{1}$ The fact that the relationship between humans and property can be divided into two categories, namely: (1) Making the heart of lust (bubbu syahwat) as the goal of their practice both physically and mentally; (2) Knowing the purpose that Allah makes lust as a examinaton to find out who is carrying out obedience and who follows their passions. Allah made property as an intermediary (wasilab) for them for the afterlife. ${ }^{2}$

Property can deliver the owners to a noble life when the acquisition and using them is carried out in a lawful manner. On the contrary, property can deliver the owners to a despicable life if the acquisition and using of them is carried out in an illegitimate way. If in our property there is a mixture between both halal and haram, separate the haram and take the remaining halal. ${ }^{3}$ The purpose of the separation is so that the property we eating does not contain any elements of prohibition either in form of substance (haram li dzatibi) or in the form of not substance (haram lighairi). Prohibition of property can occur during acquisition, management, and expenditure. The wisdom ( $\mathrm{hikmah}$ ) of prohibiting eating illegal property which are forbidden by Allah is in order to those Muslims do not fall into hellfire.

The benefit property (al-maliyah al-maslahah) is a property that is in the hands of righteous people (نعم المال الصالح للمرء الصالح). Allah has ordered humans to be scattered on the face of the earth looking for His gift through syari business, because it fact that Allah is good and will not recive something except the good ones. Syar'i business in an Islamic perspective is a part of worship to get closer to

1 Abdurahman bin Nasyir al-Sa'di, Tafsir al-Karim al-Rabman fi Tafsir Kalami al-Manan (Riyadh: Dar al-Salam, 2002), p. 128.

2 Abdurahman bin Nasyir al-Sa'di, Tafsir al-Karim al-Rabman fi Tafsir Kalami al-Manan, p. 128.

3 Abdul Halim Ibnu Taimiyah, Majmu' Fatawi (Saudi: Wazirah al-Syuuni al-Islamiyah, 2004), Juz ix, p. 273.

4 Muhammad Ibnu Ismail al-Bukhari, Al-Adab al-Mufrad, (Riyadh: al-Mathba'ah al-Salafiyah, 2011), Nomor. 299, p. 84.

5 Zakub Abdul Al-Ali dan Yasir Muhamad Abdurrahman Al-Tursani, "Musthalah al-Mal fi al-Qur'an, al-Karim wa Wasail al-Hafadh 'Alaihi fi al-Syariat al-Islamiyah," Majalah al-Ulum al-Islamiyah, Jilid 1, tt. p. 44. 
Allah.' Halal profits of business besides is used as a means to fulfill life $>$ s needs, they can also be used as a means of worship to dedicate themselves to Allah. On the contrary, the worst property (al-maliyahal-sayyiah) is a property given to humans who are in disobedience. When Allah gives property to someone who doing immorality as manifestation of disobedience it is called istidraj. إذَا رَاََيْتَ اللهَ

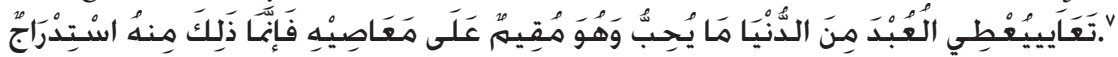

Property are one of the objectives of the protection of maqashid sharia namely hifd al-mal. Even though the ownership of property in human hands is relative, they must still get legal protection. Among the forms of property protection is the prohibition to consume property in vanity (QS. al-Baqarah $[\wedge \wedge:[r)(Q S$. an-Nisa [ $r:[\varepsilon)$, such as eating usury, stealing, looting, and others. This form of verse prohibition is general in that it is to protect private and public ownership of all businesses that are not justified. While the form of the prohibition that is specific in al-Quran for example is related to the prohibition of misuse of orphanage (QS. an-Nisa [ $r$ :[ $\varepsilon$ ). Imam Syafii said that people are masters of the things they own, and nobody has the right to take over these properties totally or partially without the consent of their owner, except in cases which are clearly specified in the law.^

The relationship between humans and property is bound by a term called ownership (milkiyah). ${ }^{9}$ Through ownership, humans can refer their property legally to meet various needs. Given the importance of property in human life, al-Quran calls it the term mata (متع) which means the source of pleasure. Of course the source of pleasure that is intended is for humans themselves. Thus it is very appropriate to be mentioned that al-Quran is very responsive to human desires, this is evidenced by the mention of terms property (al-mal) in it.' Besides contains the terms al-mal directly, al-Quran also contains other terms related to property indirectly. Therefore, exploring legal principles concerning how to manage ownership of property properly base on revelation is an important thing to serve

6 Al-Tursani, "Musthalah al-Mal fi al-Qur'an, al-Karim wa Wasail al-Hafadh 'Alaihi fi al-Syariat alIslamiyah," Majalah al-Ulum al-Islamiyah, Jilid 1, (tt), p. 44.

7 Muhammad Nashiruddin Al-Bani, Jami' al-Ahadis wa al-Atsar allati Kharajaha wa Hakama 'Alaiha ('Aman: al-Maktabah al-Islamiyah, 1422H), p. 446.

8 Lutfi Abdul Rozak and Muhammad Nabil Saupi, “The Concept and Application of Mamān al-Milkiyyah (ownership risk): Islamic Law of Contract Perspective," ISR A International Journal of Islamic Finance, Vol. 9, No. 2 (2017), p. 148-163.

9 Najih Hamad, Mu'jam al-Musthalahat al-Maliyah wa al-Iqtishadiyah fi Lughat al-Fuqaha, (Damaskus: Darul Qalam, 2008), p. 441.

10 Dahlia Haliah Ma'u, "Harta Dalam Perspektif Al-Qur'an," Jurnal Khatulistiwa-Journal of Islamic Studies, Volume 3 Nomor 12013 , p. 90 
as a guideline. The problem is how the concept of property law extractedfrom thematic verses of al-Quran?

\section{Research Methods}

This article is the result of normative legal research, ${ }^{11}$ namely research that makes law in the texts the object of study. The meaning of texts here is the verses of al-Qur>an which explains the ownershipof property (milkiyah al-amwal) so we can know the laws of how to manage propertyproperly. Because the object is in the form of verses of qur'an, the approach used is a conceptual approach. The technique of data collection is done by classifying the verses of al-Qur'an thematically (maudluiyah) about property that either use term al-mal directly or other terms which are indirectly related to al-mal. The collected verses will then be extracted through the theory of legal extracting (istinbath al-abkam) before being analyzed to release the legal meaning contained in it.

Istinbath in language means to issue. ${ }^{12}$ While in terminology the scholars have a different opinion to define term istinbath, in between is issuing the meanings (laws) from the texts of syari. ${ }^{13}$ The meanings of the syar $>i$ texts that have been released from the source then become legal products $(f i q h)$ to serve as guidelines. Understanding of sharia texts is the basis for doing legal istinbath correctly. It is impossible for someone to do istinbath without understanding the method of law extracting. The true istinbath is istinbath which matches the intrinsic meaning of a sharia scripture. ${ }^{14}$ In general, istinbath of law can be done through two approaches, namely the linguistic rule approach (al-qowaid al-lughawiyyab) and the legal goal approach (maqashid asy-syari>ah). ${ }^{15}$ The linguistic rule is used to explore the laws derived from the sharia texts (al-Qur'an and/ or al-hadith). Whereas the maqshid asy-syari $>$ ah approach aimed to understand the purposes of Islamic law through a deep reading of the sharia text. The goal of Allah establishes lawof course is to achieve human benefit (al-maslahat) both in the world and in the end.

Law is a guidance to do a actions, so in istinbath of itthey should avoid make the mistake. If there are deviant legal products, the result will be to mislead many

11 Normative legal research is also called doctrinal law research. This type of research is often conceptualized as what is written of law in books or law conceptualized as a norm which is a standard of human behavior deemed appropriate. See, Amiruddin dan Zainal Asikin, Pengantar Metode Penelitian Hukum (Jakarta: Rajawali Pers, 2003), p. 118.

12 Ahmad Ibnu Faros, Mu'jam Maqayis al-Lughah, (Beirut: Dar al-Fikri, 2010), p. 972.

13 Abdurrahman al-Sya'i, Manhaj al-Istinbath min al-Qur'an al-Karim, (Jedah: Al-Rasail al-Jamaiyah, 2006), p. 34.

14 Abdurrahman al-Sya'i, Manhaj al-Istinbath min al-Qur'an al-Karim, p. 142.

15 Abd. Rahman Dahlan, Ushul Fiqh, p. 242. 
people. The causes deviations in istinbath the verses of al-Qur'an are: (1) there is deviations related to aqidah (al-inharaffi al-aqidab); (2) mistakes in understanding the nature of al-Qur'an (al-inharaffifahmi ma > anibathin al-Qur>an); (3) deviations in interpretation (al-inharaffi tafsir); (4) prioritizing reason rather than sharia (taqdim al-aqli 'ala al-naqli); (5) the level of faithtoward the meaning of the verses then clings to it (itiqad al-ma>anitsummahamlu al-ayati 'alaiba). ${ }^{16}$ The deviations of aqidah will have an effect on deviations from the essential meaning of the verses of al-Qur'an. Deviations of the essential meaning of them, will make it easy for someone to deny Quran as a representation of Allah desires. The fact that misinterpretation the verses of al-Qur'an is possible occurs in our society either intentionally by following lust or not. The misinterpreting the Qur>anic will accur when they interpret verses that comes out of the real meaning. Turned the meaning of Qur'an intentionally to resemble the Jews who changed the Torahas confirmed in word of Allah: يحرفون الكله عن مواضعه (QS. an-Nisa [4]: 46).

\section{Discussion}

\section{The Istinbath of Property Law of al-Qur'an}

Islam provides an adequate guideline for the beneficial use of property so as to derive the optimum advantages from one's possession. ${ }^{17}$ In the Islamic perspective, propertyis derived from Allah which is given to humans ( $Q S$. an-Nuur [24]: 33). Based on that verse, it is understood that Allah is the owner of property in absolute terms, while the ownership of them in the hands of humans is relative to be used in accordance with his nature. ${ }^{18}$ The acquisition and its utilization of property by humans will be held accountable to the Allah. In a hadith it is stated that the right of humans will not shift on the Day of Judgment until he is asked four things, including about where the property was obtained and for what the asset was spent (من أين اكتسبه وفِيما أنفقَقَه؟). how to acquire and spend property shows that understanding the legal concept of property (ahkam al-amal) in the perspective of al-Qur'an is a necessity.

Allah has given rizki to all His creatures on earth (QS. Huud [11]: 1). But in the matter of giving rizki, Allah is the one who makes it extensiveand narrow

16 Abdurrahman al-Sya'i, Manhaj al-Istinbath min al-Qur'an al-Karim, p. 350.

17 Hayatullah Laluddin, Mohd Nasran Mohamad, Zaini Nasohah, Shofian Ahmad, "Property and ownership rightfrom an Islamic Perspective," Advances in Natural and Applied Sciences, Vol. 6, No. 7 (2012), p. 1127.

18 Abdurahman bin Nasyir al-Sa'di, Tafsir al-Karim al-Rahman fi Tafsir Kalami al-Manan, hlm. 664.

19 Abdul Shamad Al-Darami, Musnad al-Darami (Riyadh: Dar al-Mughni, 2000), Juz I, No. 554, p. 453. 
(QS. al-Ankabut [ 19]: 1 1) and to overestimate your part from others (QS. an-Nahl: v) ). Through differentiation of rizki, it is expected there is mutual cooperation is (QS. az-Zukhruf $[\varepsilon r] r r$ ) in accordance with conditions (QS. az-Zumar $[r q]: r q$ ) (QS. Al-Israa [IV]: $\wedge \varepsilon$ ) and efforts each other (QS. al-Lail [9r]: $\varepsilon$ ). Rizki that has been given by Allah will be the ownership right for those who receive it. However, to get the rizki, there are the causes of ownership either effortly (al-milkiyah alibtiyariyah) such as trading, farming, raising livestock, etc. or ownership from the gifts (al-milkiyah al-ithaiyah) such as through zakat, infaq, warisan, wasiat, bibah, etc.

$\mathrm{Al}$-Qur'an as the main legal source certainly contains principles that can be used as guidelines for propertymanagement. Explanation of propertyin al-Qur'an directly use term mal (المال)that the plural form is أموال is derived from the verb مول. At first, the ownership of propertywas in the form of gold and silver money which then extended to all ownership of valuables things. ${ }^{20}$ In terminology, there are various opinions about the definition of property, including everything that can be taken to meet human needs. ${ }^{21}$ Mal means all things which are capable of being owned. ${ }^{22}$ Property can be in the form of money or other assets that can be used as a means to fulfill needs and worship to Allah. The following is some terms property in al-Quran according Al-Tursani ${ }^{23}$ which is directly related to this topic.

Tabel 1.The Words Property in Al-Qur'an

\begin{tabular}{|c|c|c|c|c|c|}
\hline NO & $\begin{array}{l}\text { The Form of } \\
\text { Word }\end{array}$ & \multicolumn{2}{|c|}{$\begin{array}{c}\text { Number of } \\
\text { Word }\end{array}$} & $(\%)^{2}$ & $\begin{array}{c}\text { Form of Word } \\
\text { Changing }\end{array}$ \\
\hline \multirow{2}{*}{1} & أموالكم & 11 & & & \\
\hline & بأموالكم & 3 & 14 & $16 \%$ & الجمع المخاطب \\
\hline \multirow{2}{*}{2} & أموالهم & זr & \multirow{2}{*}{ ए } & \multirow{2}{*}{ ५า\% } & \multirow{2}{*}{ الجمع الغائب } \\
\hline & بأموالهم & $\Lambda$ & & & \\
\hline r & ماله & 7 & 7 & V\% & المفرد الغائب \\
\hline$\varepsilon$ & أموالنا & r & r & $r \%$ & جمع المتكلم \\
\hline 0 & ماليه & 1 & 1 & $1 \%$ & المفرد المتكلم \\
\hline
\end{tabular}

20 Ibnu Mandhur, Lisan Al-Arabi (Beirut: Dar Ihya al-Turas al-'Arabi, 1414H), Juz 11, p. 636.

21 Ibnu Mandhur, Lisan Al-Arabi, Juz 11, p. 636.

22 Muhammad Wohidul Islam, "Al-Mal: The Concept of Property in Islamic Legal Thought," Arab Law Quarterly, Vol. 14, No. 4, (1999), p. 361.

23 This data is processed from the results of research Zakub Abdul Al-Ali dan Yasir Muhamad Abdurrahman Al-Tursani,"Musthalah al-Mal fi al-Qur'an, al-Karim wa Wasail al-Hafadh 'Alaihi fi al-Syariat al-Islamiyah," Majalah al-Ulum al-Islamiyah, Jilid 1 (tt), p. 38. 


\begin{tabular}{|c|c|c|c|c|c|}
\hline 7 & الآموال & r & 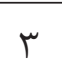 & $乏 \%$ & جمع المعرفة \\
\hline V & المال & $\varepsilon$ & $\varepsilon$ & $0 \%$ & المفرد المعرفة \\
\hline \multirow{3}{*}{$\Lambda$} & أموالا & r & \multirow{3}{*}{11} & \multirow{3}{*}{$1 \mu_{0}$} & \multirow{3}{*}{ جمع النكرة } \\
\hline & أموال & 7 & & & \\
\hline & بأموال & r & & & \\
\hline \multirow{3}{*}{9} & مالا & V & \multirow{3}{*}{$1 \varepsilon$} & \multirow{3}{*}{$17 \%$} & \multirow{3}{*}{ مفرد النكرة } \\
\hline & مال & 7 & & & \\
\hline & بمال & 1 & & & \\
\hline & & & $\begin{array}{l}86 \\
\text { al-' } 2\end{array}$ & $\begin{array}{l}100 \% \\
\text { lamiyah }\end{array}$ & \\
\hline
\end{tabular}

Term $\mathrm{JLL}$ and its alteration (tasrifiyah) mentioned above are related to various explanations, such as the nature of ownership (QS. an-Nuur: $\mu$ ) (QS. al-Muddassir: 1 I), the intruction of zakat/shadaqah (QS. at-Taubah: 1.r), 'infaq

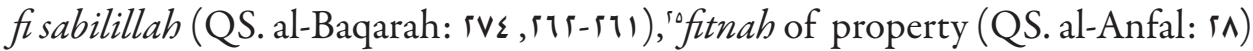
(QS. al-Mukminun: 07-00) (QS. at-Taghabun: 10), infaq of the infidels (QS. alAnfal: $r$ ), the position of person who strive with property (QS. at-Taubah: $r \cdot$ ), prohibition on eating property in vanity (QS. an-Nisa: rq) (QS. at-Taubah: $r \varepsilon$ ), prohibition on the amazement of property (QS. at-Taubah: $\wedge \Delta)$, property as jewelery (QS. al-Kahf: 21 ), prohibition of negligence by property (QS. al-Munafiqun: 9), prohibition of excessive love of property (QS. al-Fajr: $\uparrow \cdot$ ), the prohibition of accumulating property in excess (QS. al-Humazah: $\boldsymbol{r}^{-1}$ ), and others.

The discussion of property in the verses of al-Qur'an besides can be understood from term $\mathrm{J} L \mathrm{~L}$ and its alteration (tasrifyah), it can also be understood by other terms which direct in the context of property, for example the related verses invoke rizki (QS. al-Baqarah: ros) (QS. an-Nahl: vo), love of silver and gold/ livestock/ field rice fields (QS. Ali-Imran: 1 $\varepsilon$ ), prohibition of extravagance (QS. al-Isra>: $\lceil V-[1$ ), the story of Korun (QS. al-Qashash: $V \wedge-V 1)$, prohibition on dignity (QS. at-Takatsur: $\Lambda-1)$, prohibition on usury (QS. al- Baqarah: ivo), prohibition on stealing (QS. al-Maidah: $r \wedge$ ), verses relating to contracts such as buying and selling

24 The insruction of zakat/ shadaqab in Qur'an not only concerning term al-mal but also other terms for example (QS. al-Baqarah [2]:110), QS. al-Ambiya [21]: 73), (QS. al-Hajj [22]:41), (QS. Luqman[31]: 4), (QS. al-Fatir[35]: 29), (QS. al-Fushilat [41]: 7), (QS. al-Muzzamil [73]: 20), (QS. al-Mujadilah[58]: 13), (QS. al-Bayyinah[98]: 5).

25 The insructionof infag in Qur'an not only concerning term al-mal but also other terms for example (QS. al-Baqarah [2]: 195, 254, 267, 273), (QS. ar-Ra'd [13]: 22), (QS. al-Hadid [57]: 7, 10), (QS. alMunafiqun [63]: 10). 
(QS. al-Baqarah: ivo), debt agreement (QS. al-Hadid: 11), etc, as well as other verses relating to orders scattered on the face of the earth looking for rizki (QS. al-Mulk: 10) (QS. al-Jumu>ah: 1.) to continue life.

The ownership of property is absolutely God $>$ s right, while human ownership is relative. This belief is part of the practice of taubid rububiyah, namely affirming the oneness of Allah in His actions and powers. This means that God has power over everything in the universe including giving blessings (rizki) to all of his creatures. Property as a form of rizki are derived from Allah given to humans as a means for worship and fulfilling their daily needs. The legal basis for the ownership of property comes from Allah: من مال الله الذي اتاكم. Its mean that the property entrusted to humans is a small part of God $>s$ property so that it is used to do good." Allah when giving property to humans is different because there are of them that are diluted and some are narrowed according to each condition.

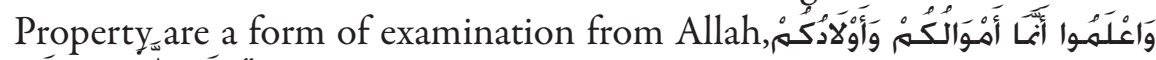
in this verse is the instruction of Allah for humans to know the warning of the slander (fitnab) inherent in property. The meaning of terms fitnah in language is a temptation. Fitnah coming of Allah like as a disaster as the punishment of deviant deeds. Whenever a disaster occurs it can be used as a lesson for humans in order to not violate Allah $>$ s commands. .v Property are declared as a examination because they can bring good or bad to the owner. Whoever succeeds in passing that examination, they will be judged as worship and so will receive a great reward. On the contrary, anyone who fails to face that examination, they will get a painful punishment both in the world and in the hereafter. According to Jaafar, property is recognized by shariah as the basic for meaningful life and prerequisite for human beings to execute their dual functions as servants to Allah and vicegerent of mankind. In Islam, a good life is attained through the balanced satisfaction of material and spiritual needs of man. "Muslim must strive in Allah's cause with his wealth and his self'(QS. as-Saff: 11$).^{\text {'N }}$

To sustain living, humans need an effort to get the source of livelihood provided by Allah on the face of the earth (QS. al-A>raf: 11). By that living, humans are capable to worship. The propertyas one of instruments of worship, they have law which is instructively. Verse quotation iَ is a example intruction to collect the property from rich people (muzakki) who are reluctant to pay zakat. 26 This verse is related to the order to deliver slaves, Ibnu Katsir, Tafsir al-Qur'an al-'Adhim (Riyad: Dar Thayyibah, 1997), Jilid 1, p. 222.

27 Al-Raghib al-Ashfahani, Al-Mufradat fi Gharib al-Qur'an (Riyadh: Maktabah Musthafa Baz, 2009), juz I, p. 482.

28 Amalina Abdullh and Junaina Muhammad, "Ethical Values in Islamic Financial Planning," Jurnal Pengurusan, Vol. 28 (2013), p. 134. 


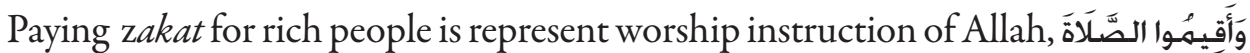
مثل الذين أنوالههم في سبيل:Other form ofinstruction such as infagfisabilillah وَاتَوا الزَّكَاةً الله كمثل حبة أنبتت في كل سنبلة مائة حبة والله يضاعف لمن يشـاء اللهاء. This verse describes the form of reward multiplication with an example that can be witnessed by the eyes of the heart. Then the testimony is strengthened by the eyesight, in order to humans practice the infaq with full comfort/ generosity to get multiple rewards. ${ }^{\text {rq }}$ The multiplication of reward in the example of that verse shows the existence of the instruction, as the word of Allah: وَأَنْفقُوا فِي سَبِيل اللهِ . Indeed, the infaq that is fulfilled is a form jihad with property as well as the obligation of jihad physically. By infaq fi sabilillah, there is a great benefit (maslahat) to develope the Muslims capacity and to uphold the dignityof Allah's religion.'

Allah has given abundant property to humans (QS. al-Muddasir: 15). Among humans there are those who love property properly and there are those who love excessively (QS. al-Fajr: $\uparrow \cdot$ ). This very excessive love is characterized by the word حُبَّن which functions as an maf>ul mutlaq to strengthen word A effect of excessive love for property can cause people to be reluctant to spend them. Humans who love wealth excessively tend to live in swanky (mutakasirun) and arrogantly take pride in property (mufataharun) until neglect of remembering Allah. Even if the negligence is not immediately realized, they will continue until enters the grave (QS. at-Takatsur: $[-1$ ) and even in hereafter they will be be held accountable of swanky before entered in jahannam (QS. at-Takatsur: $1-1$ ).

Infaq is commanded by Allah because in the property of rich people there

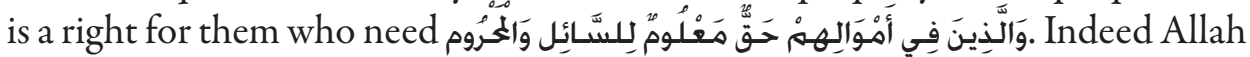
has limited the propertyof good people(al-ihsan) by setting aside the rights for sail and mahrum." It means that in our property there is a right allocated in the form of zakat for sail namely indigents (al-faqirun) who beggars and mabrum namely the indigents who not beggars." The aim of the indigents not to beg (al-mutaafif) is to protect their dignity, even though actually they need help. Besides the needy, there is also a group of people who refrain from asking for help immediately (因

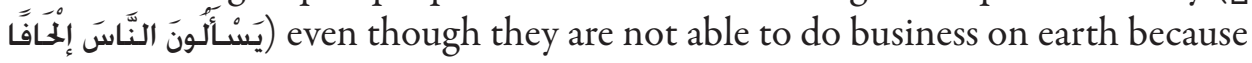
they are bound by jihad fisabilillah. Although ignorant people think they are rich,

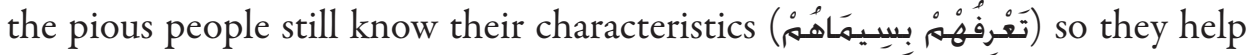
them immediately. Because it is unlawful to behave harshly towards the begging (QS. adh-Dhuha: 1•).

29 Abdurahman bin Nasyir al-Sa'di, Tafsir al-Karim al-Rabman fi Tafsir Kalami al-Manan, p. 110.

30 Abdurahman bin Nasyir al-Sa'di, Tafsir al-Karim al-Rabman fi Tafsir Kalami al-Manan, p. 88.

31 Muhammad Mutawali Sya'rawi, Tafsir al-Sya'rawi (Riyadh: Ahbarul Yaum, 2012), juz ii, p. 1208.

32 Al-Thabari, Jami' al-Bayan an Ta'wili al-Qur'an (Beirut: Muasasah al-Risalah, 2014), jilid vii, p. 381. 
Besides the command, the form of obedience to Allah also can be realized by avoiding prohibitions related to property, for example the prohibition of riya when do infaq by bringing up the giving that can hurt the recipient $>s$ feelings.

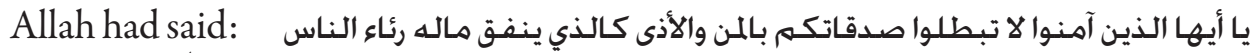
ولا يؤمن بالله واليوم الآخر. The verse confirms that mentioning giving that hurt the recipients feelings can invalidate shadaqah. ${ }^{r r}$ Leveraging giving is a manifestation of lack of sincerity so that it can plunge the culprit into riya, namely practice because humans are not because of Allah. Illegal practices like riya are likened to slippery rocks كَمَتَل صَفْفوَانَ on which there is the land which its above was hit by

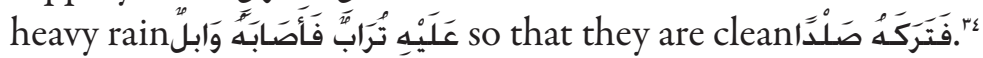

Examples of other prohibition isdo infaq with bad property as the word

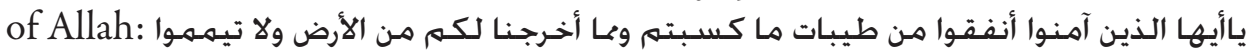

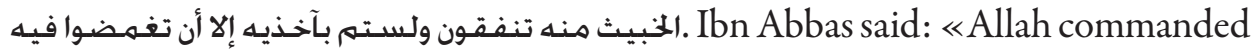
them to do infaq with the good property and forbid infaq with the bad one. Indeed Allah is good and will not accept except something that is good." ${ }^{\text {"ro }}$ Scholars have differences of opinion in about the definition of infaq, namely there are who say it is obligatory like zakat and some say it is al-tathawu. Terms طَيِّبَاتِ its means good choiceproperty obtained from the lawful business, ${ }^{r 1}$ such as assets from agricultural products through agriculture, mining, and others that are not contrary to the sharia principles. Beside the prohibition on applying illegal property, it is also recommended to invest in good quality assets.

From the results of the excavation the verses of al-Qur'an, the law concerning property can be mapped as follows:

33 Abdurahman bin Nasyir al-Sa'di, Tafsir al-Karim al-Rahman fi Tafsir Kalami al-Manan, p. 116. 34 Abdurahman bin Nasyir al-Sa'di, Tafsir al-Karim al-Rahman fi Tafsir Kalami al-Manan, p. 116. 35 Ibnu Katsir, Tafsir al-Qur'an al-'Adbim, Jilid 1, p. 696-697.

36 Al-Qurtubi, Al-Jami' a-ILlkam al-Qur'an (Beirut: Muasasah al-Risalah, 2002), Juz iv, p. 342-343. 
Tabel 2. Property Law in Al-Qur'an

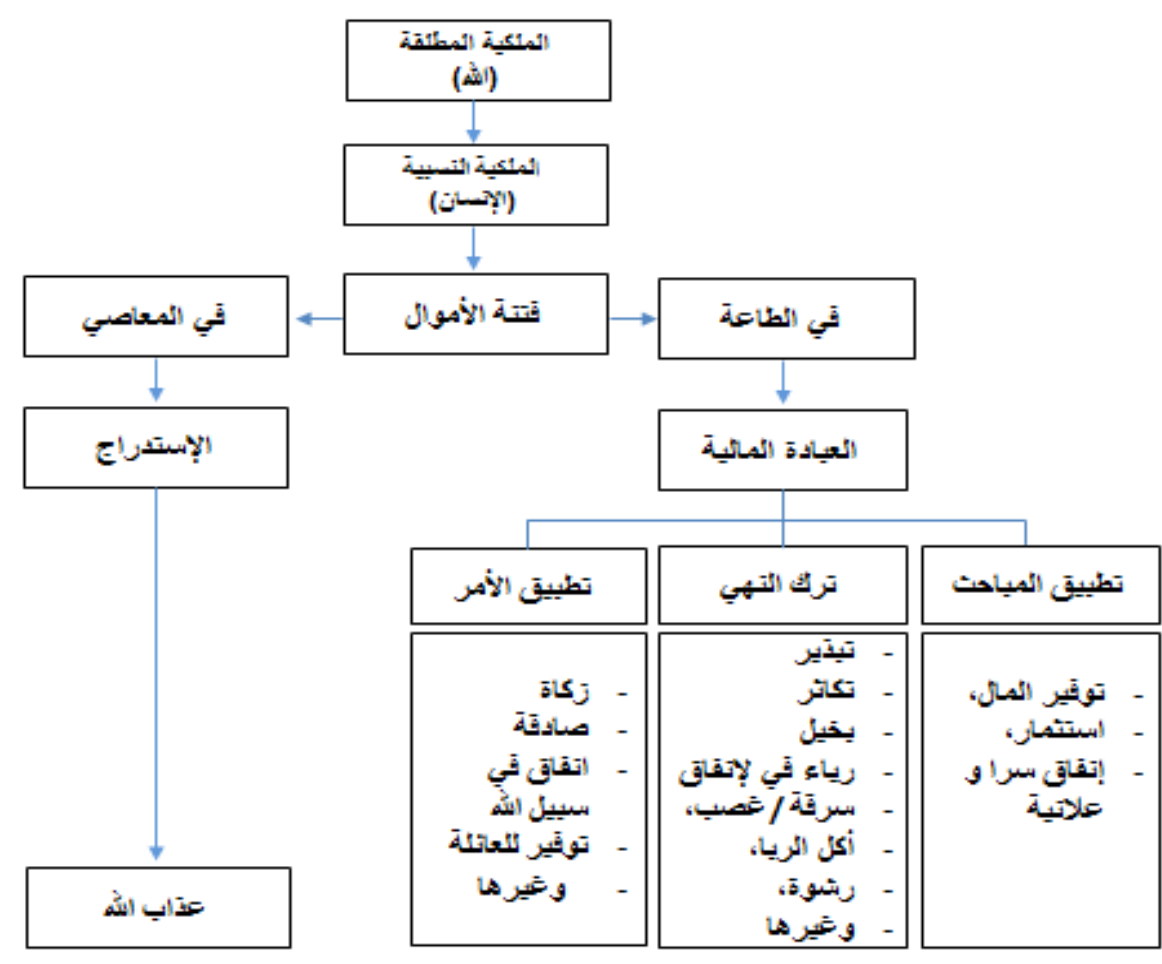

Source: Al-Qur'an

\section{Conclusion}

Study of propertyin al-Qur'an beside using the term J山l and its alteration (tasrifiyah), it can also be understood by other terms which leads tocontext of property. The ownership of property is absolutely the right of Allah, while the ownership in the hands of humans is relative because it is a mandate that will be held accountable. The benefit property (al-maliyahal-maslahab) is a property that is in the hands of righteous people, because it is not only used to fulfill their needs of life, but also is used as a means of worship to draw closer to Allah. On the contrary, the worst property (al-maliyah al-sayyiah) is a property given to humans who are in disobedience. Giving fo Allah to people who are committing acts of immorality is a form of istidraj. The position of property underperspective of al-Qur>an is a examination for humans (fitnab). If the exam can be passed properly through obedience, it will be worth the worship of property good in the form of instructions, prohibitions, and permisions. On the contrary, failure to 
face the examination of property can lead the owner to istidraj by doing immoral, sothey will get the $a z h a b$ of Allah.

\section{References}

Book

Al-Ashfahani, Al-Raghib. Al-Mufradat fi Gharib al-Qur'an. Riyadh: Maktabah Musthafa Baz, 2009.

Al-Bani, Muhammad Nashiruddin. Jami al-Ahadis wa al-Atsar allati Kharajaha wa Hakama 'Alaiha. 'Aman: al-Maktabah al-Islamiyah, $1422 \mathrm{H}$.

Al-Bukhari, Muhammad Ibnu Ismail. Al-Adab al-Mufrad. Riyadh: al-Mathba'ah alSalafiyah, 2011.

Al-Darami, Abdul Shamad. Musnad al-Darami. Riyadh: Dar al-Mughni, 2000.

Al-Qurtubi. Al-Jami' a-Iblkam al-Quran. Beirut: Muasasah al-Risalah, 2002.

Al-Sa'di, Abdurahman bin Nasyir. Tafsir al-Karim al-Rahman fi Tafsir Kalami alManan. Riyadh: Dar al-Salam, 2002.

Al-Syåi, Abdurrahman. Manhaj al-Istinbath min al-Qur'an al-Karim.Jedah: Al-Rasail al-Jamaiyah, 2006.

Al-Thabari.Jami al-Bayan an Táwili al-Qur'an. Beirut: Muasasah al-Risalah, 2014.

Al-Zuhaili, Wahbah. Al-Tafsir al-Munir fi al-Aqidah wa al-Syariah wa al-Manhaj. Beirut: Dar al-Fikri, 1991.

Amiruddin dan Zainal Asikin.Pengantar Metode Penelitian Hukum.Jakarta: Rajawali Pers, 2003.

Al-Ali, Zakub Abdul dan Yasir Muhamad Abdurrahman al-Tursani,"Musthalah al-Mal fi al-Qur'an, al-Karim wa Wasail al-Hafadh 'Alaihi fi al-Syariat al-Islamiyah," Majalah al-'Ulum al-Islamiyah, tt.

Dahlan, Abd. Rahmad. Ushul Figh. Jakarta: Penerbit Amzah, 2010.

Faros, Ahmad Ibnu. Mu'jam Maqayis al-Lughah. Beirut: Dar al-Fikri, 2010.

Hamad, Najih. Mu'jam al-Musthalahat al-Maliyah wa al-Iqtishadiyah $f i$ Lughat alFuqaha. Damaskus: Dar al-Qalam, 2008. 
Katsir, Ibnu. Tafsir al-Qur'anal-Adhim. Riyad: Dar Thayyibah, 1997.

Mandhur, Ibnu. Lisan Al-Arabi. Beirut: Dar Ihya al-Turas, al-Arabi, 1414H.

Namri, Ali. Al-Mal fi Mizani al-Syariah al-Islamiyah. Alalukah, 2015.

Sya'rawi, Muhammad Mutawali. Tafsir al-Sya'rawi. Riyadh: Ahbarul Yaum, 2012.

Syarifuddin, Amir. Ushul Fiqh. Jakarta: Prenanda Kencana, 2011.

Taimiyah, Abdul Halim Ibnu. Majmu' Fatawi. Saudi: Wazirah al-Syuuni al-Islamiyah, 2004.

Article

Abdullah, Amalina and Junaina Muhammad. "Ethical Values in Islamic Financial Planning," Jurnal Pengurusan, Vol. 28 No. 1: 2013.

Haliah, Dahlia. "Harta Dalam Perspektif Al-Qur'an," Jurnal Khatulistiwa-Journal of Islamic Studies, Vol. 3 Nomor 1: 2013.

Islam, Muhammad Wohidul. "Al-Mal: The Concept of Property in Islamic Legal Thought," Arab Law Quarterly, Vol. 14, No. 4: 1999.

Laluddin, Hayatullah, and Others. "Property and ownership rightfrom an Islamic Perspective," Advances in Natural and Applied Sciences, Vol. 6, No. 7: 2012.

Rozak, Lutfi Abdul and Saupi, Muhammad Nabil. "The Concept and Application of Mamān al-Milkiyyah (ownership risk): Islamic Law of Contract Perspective," ISRA International Journal of Islamic Finance, Vol. 9, No. 2: 2017. 